Iranian Quarterly Journal of Breast Disease. 2019; 12(3):36.
Receive: $28 / 4 / 2019$

Accepted: 4/8/ 2019

*Corresponding Author: assajadi@yahoo.com

Ethics Approval: IR.ACECR.IBCRC.REC.1395

\section{Original Article \\ Depression, Anxiety, and Quality of Life of Breast Cancer Patients' Husbands Before and After Treatment}

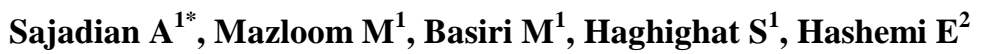 \\ ${ }^{1}$ Quality of Life and Integrative Oncology Department, Breast Cancer Research Center, \\ Motamed Cancer Institute, ACECR, Tehran, Iran \\ ${ }^{2}$ Clinical Research Department, Breast Cancer Research Center, Motamed Cancer \\ Institute, ACECR, Tehran, Iran
}

\begin{abstract}
Introduction: The incidence of breast cancer poses a variety of physical and psychological stresses to the patients and their families, especially husbands. The aim of this study was to evaluate anxiety, depression, and quality of life of husbands of breast cancer patients before and after cancer treatment.
\end{abstract}

Methods: In this descriptive study, we recruited husbands of breast cancer patients $(n=142)$ under treatment at the Breast Cancer Clinic of the ACECR. The participants completed the Beck Depression Inventory, Beck Anxiety Inventory, and SF-36 before and after completion of their wives' treatments.

Results: The husbands had significantly lower anxiety $(\mathrm{p}<0.001)$ and depression $(p<0.002)$ following their wives' treatment However, their sexual satisfaction had declined at the posttreatment period. The mean scores on three dimensions of quality of life, i.e., physical functioning, general health perception, and mental health, were also declined after the treatment. Most of the husbands had more physical problems after the treatment of their spouses.

Conclusion: It is necessary for health and medical organizations to provide extensive educational services and behavioral interventions to the patients and their families at different stages of diagnosis and treatment.

Keywords: Husbands, Breast Cancer, Anxiety, Depression, Quality of Life 


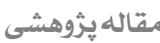

مقايسه اضطراب، افسردكى و كيفيت زندكى همسر بيماران مبتلا به

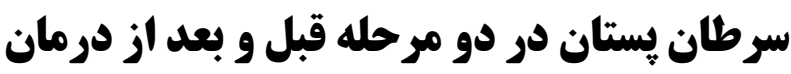

اكرمالسادات سجاديان"'، مريم مظلوم'، مريم بصيرى'، شهير حقيقت'، عصمتالسادات هاشمى'

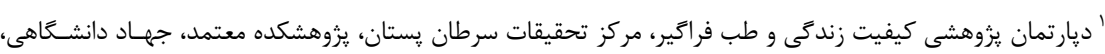
كتيران، ايران

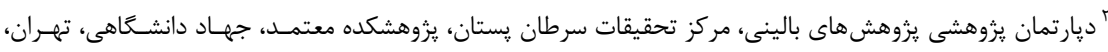
ايران
فصلنامه بيمارى هاى يستان ايران

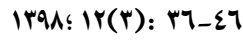

\section{جكيده}

مقدمه: بروز سرطان قِستان آسيبهاى جسمى و روانسى بسـيارى را بـراى بيمـار و خـانواده او و

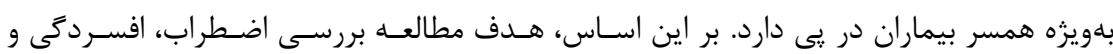

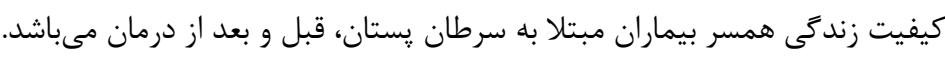

روش بررسى: يزوهش حاضر، يك مطالعه توصيفى است كه در دو مقطع به فاصله حسدود شـش

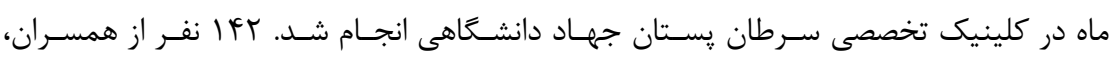

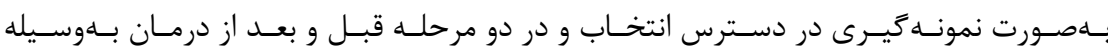

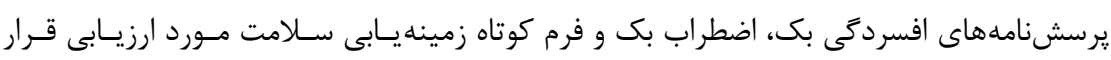
كرفتند.

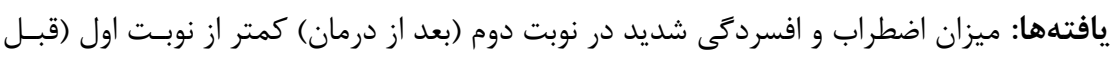

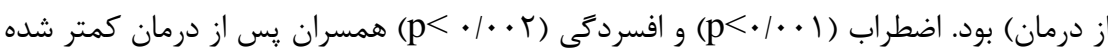

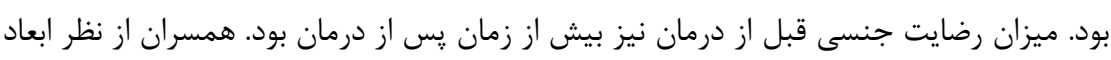

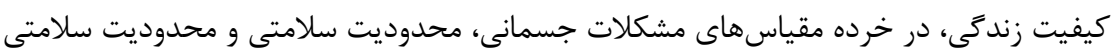

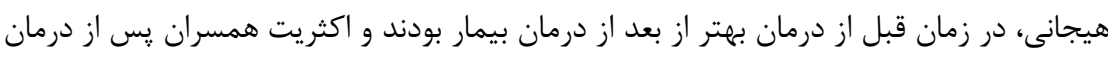
بيمار مشكلات جسمى بيشترى داشتند. نتيجدكيرى: براساس يافته هاى يزوهش مبنى بر سطوح متفاوت مشكلات جسمانى، اضـطراب و

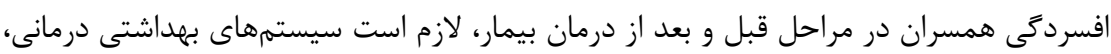

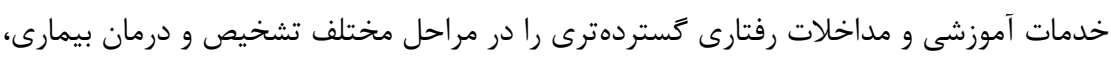
براى بيمار و خانواده بيمار ارايه نمايند. |وازههاى كليدى: همسران، سرطان پِتان، اضطراب، افسردگى، كيفيت زندگى

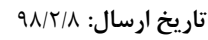

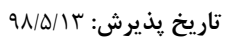

"نويسنده مسئول: assajadi@yahoo.com 
سلامت همسرشان و شناسايى راهبردهاى مقابله با بيمارى

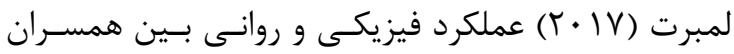

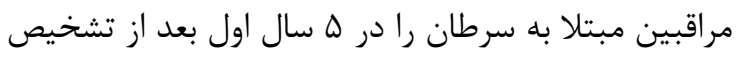

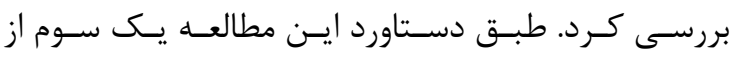

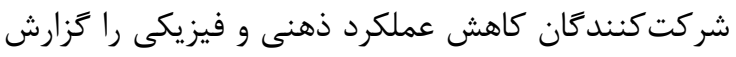

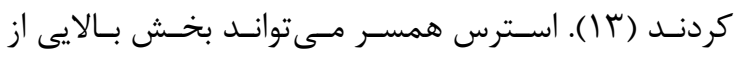

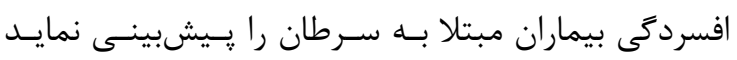

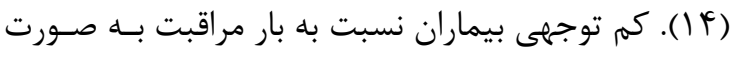

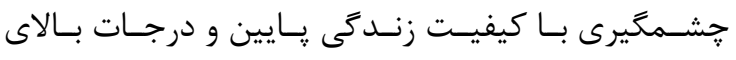

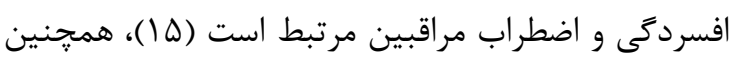

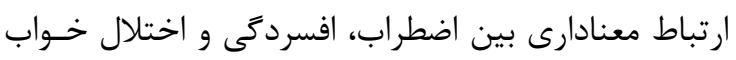

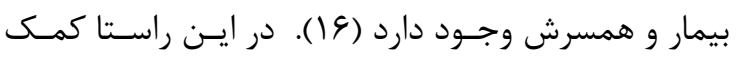

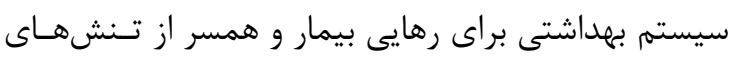

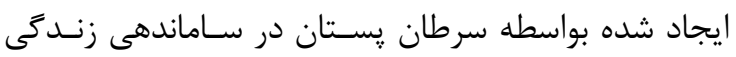

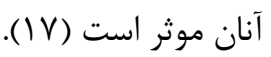

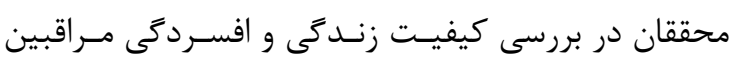

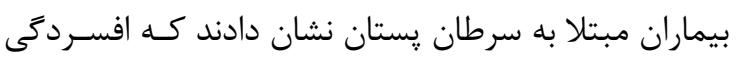

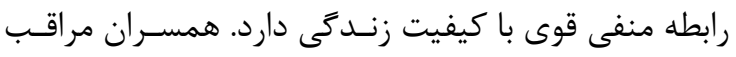

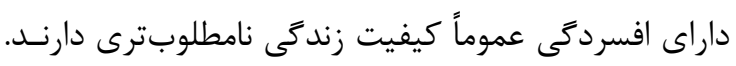

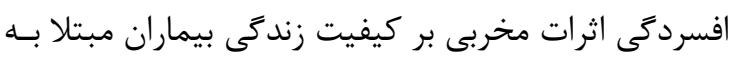

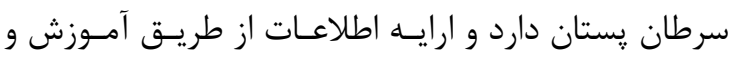

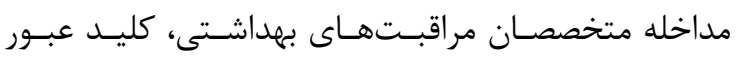

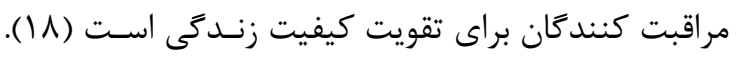

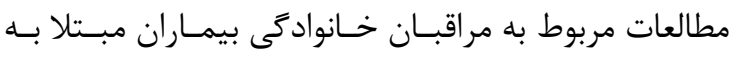

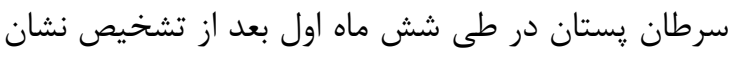

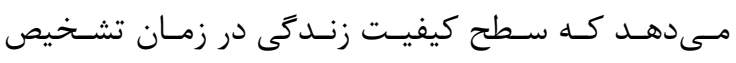
ريشبين قوىترى نسبت به تغييرات سطح كيفيت زندكى

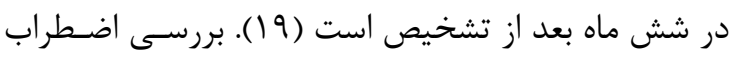

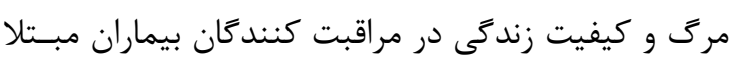

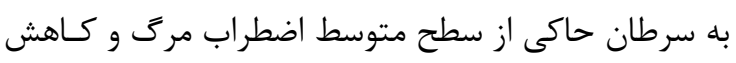

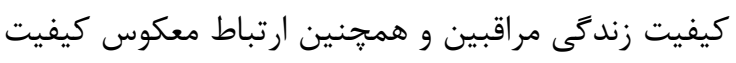

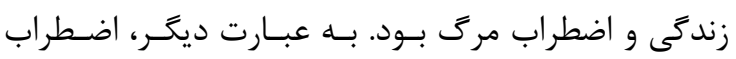

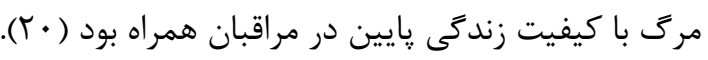

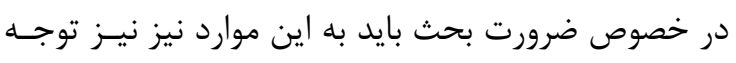

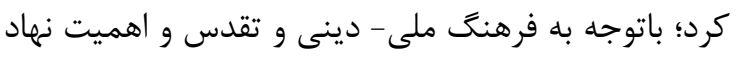

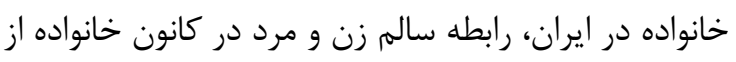

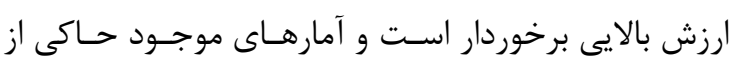
احتمال ابتلا به سرطان يستان در ايران در سنين بايينتـر

با ابتلا به سرطان يستان، عموماً بيماران دجار آشفتگىهاى

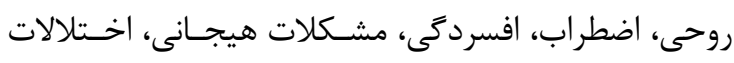

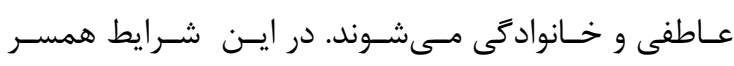

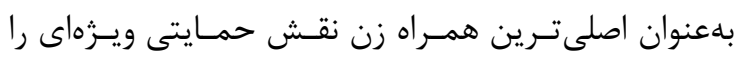

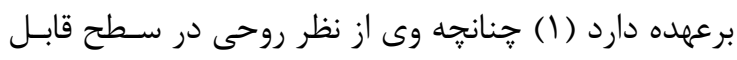

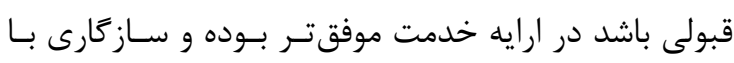

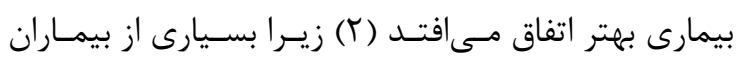

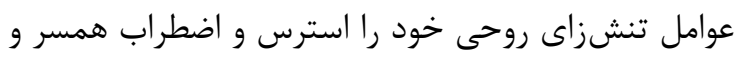

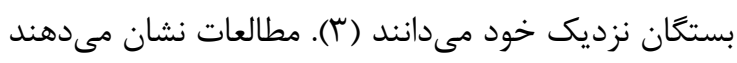

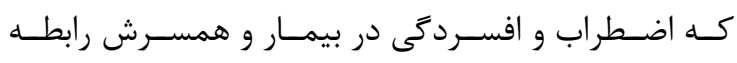

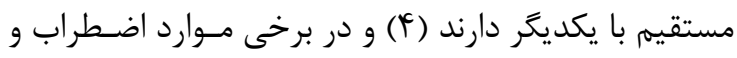

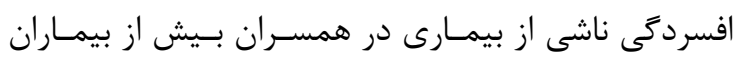

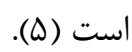
محققان نشان دادند كه اكثريت مراقبين (همسر بيمـاران)

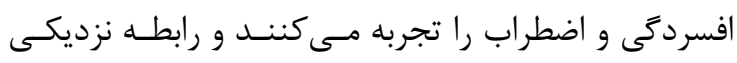

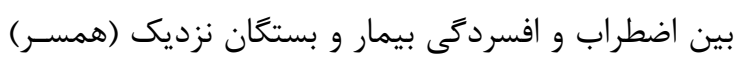

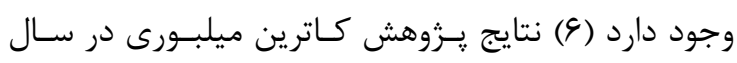

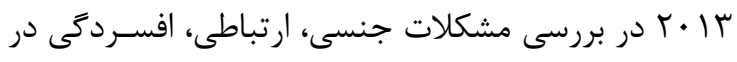

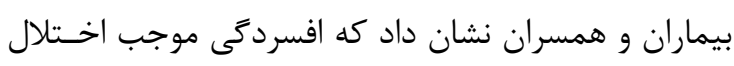

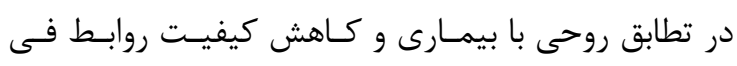

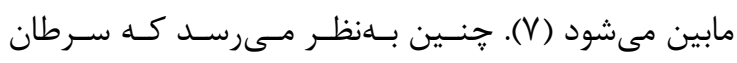

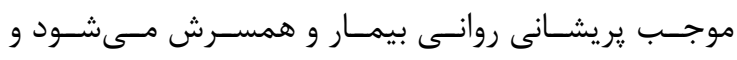

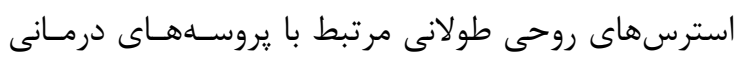

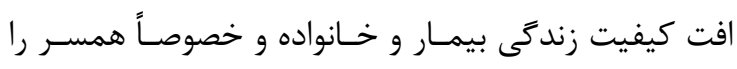

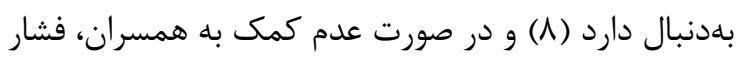

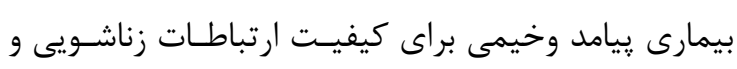

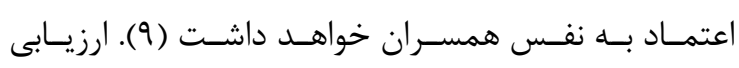

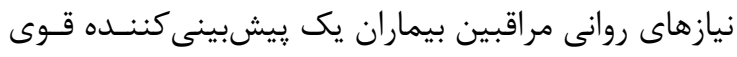

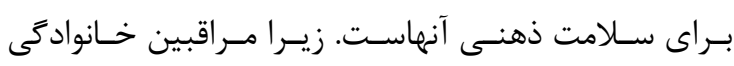

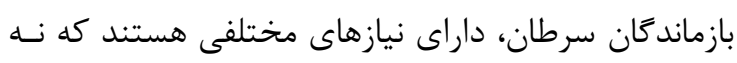

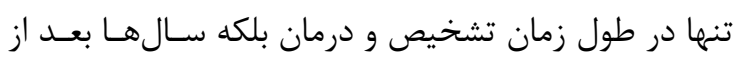

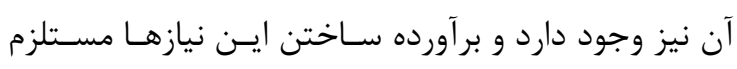

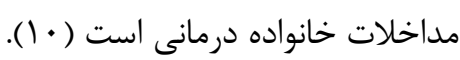

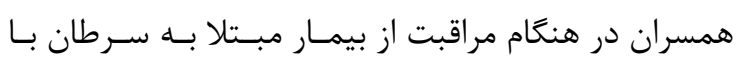

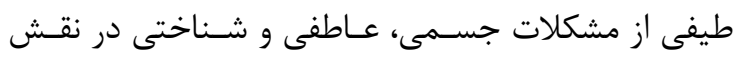

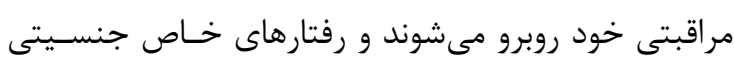

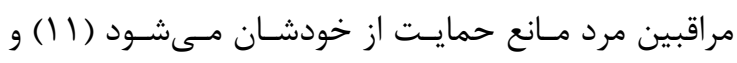

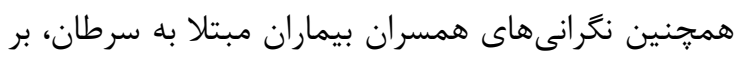




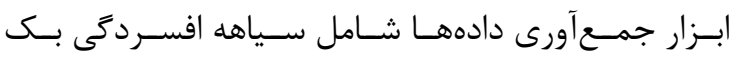

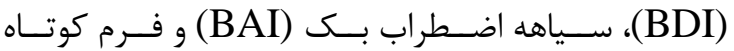
زمينهيابى سلامت (SF-36) بود.

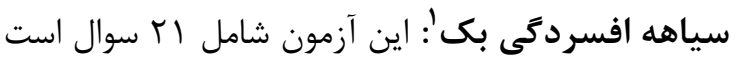

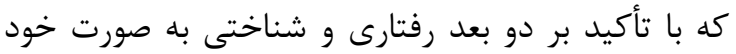

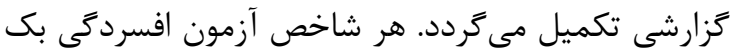

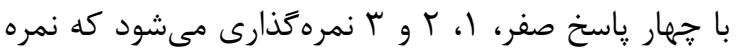

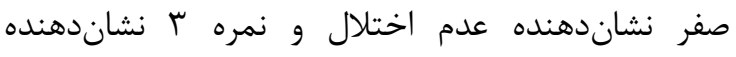

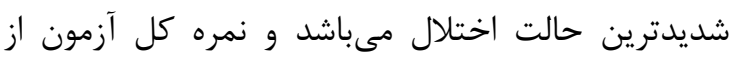
صفر تا سو متغير است. براى تحليل، نمرات تمامى سوالات

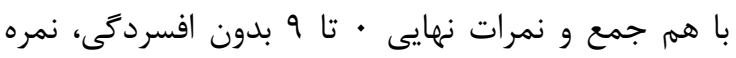

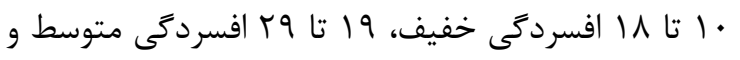

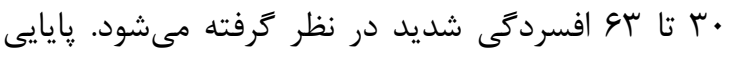

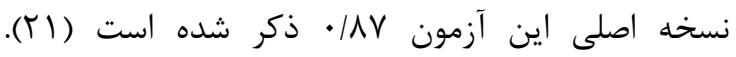

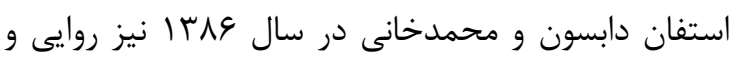

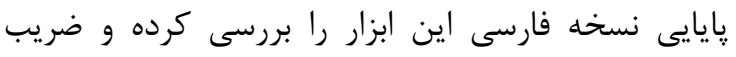

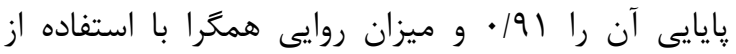

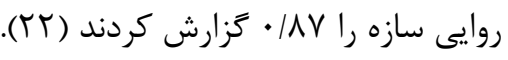

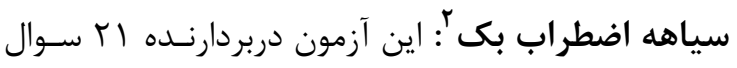

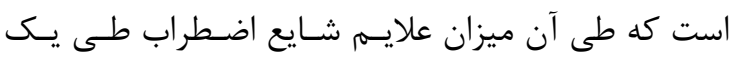

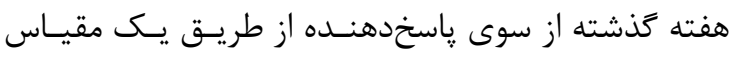

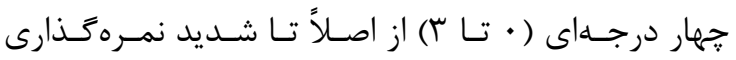

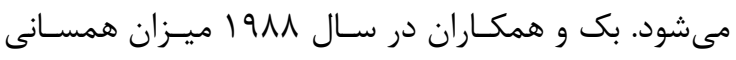

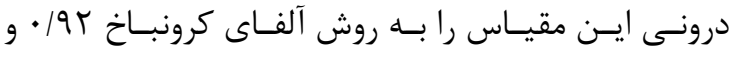

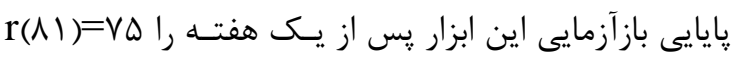

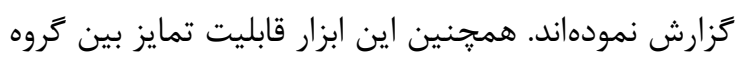

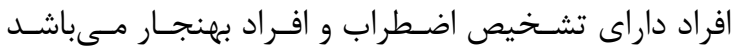

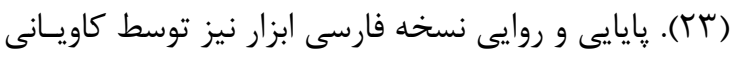

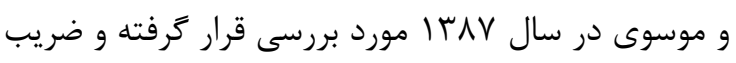

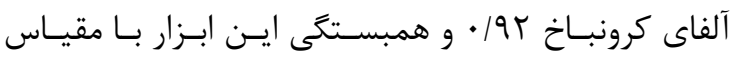

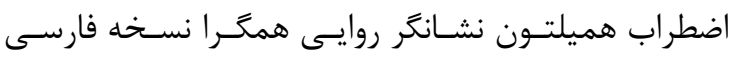

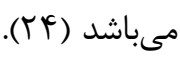

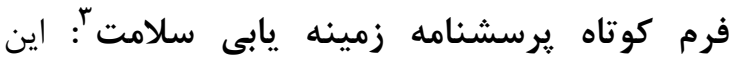

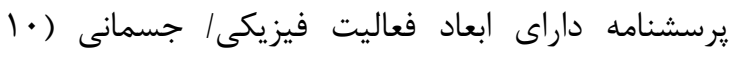

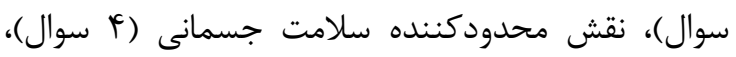
نقش محدودكننده در مشكلات عاطفى (r سوال)،

\footnotetext{
${ }^{1}$ Beck Depression Inventory (BDI)

${ }^{2}$ Beck Anxiety Inventory (BAI)

${ }^{3}$ Short-Form (36) Health Survey (SF-36)
}

(بــارورى و ابتـداى تشـكيل خـانواده) مسىباشــد، امــا در بررسـىهــاى انجـام شـده در ايــــان، از ميـزان مشـكلات روانشناختى نظير اضطراب و افسردىى در همسر بيمـاران

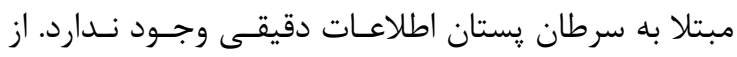
طرف ديكر كزارشهايى مبنى بر لزوم حمايتهاى روانسى عاطفى همسران از بيمار خود نيز وجود دارد (1).

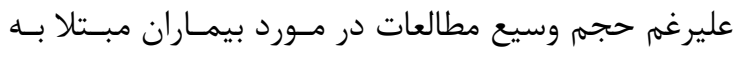
سرطان يستان، مطالعات اندكى در مورد همسران بيمـاران

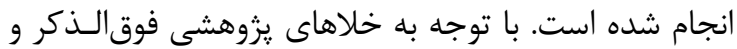

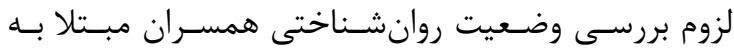

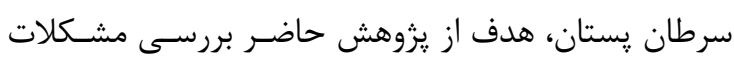

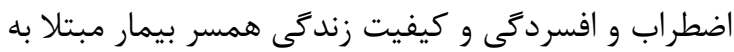
سرطان يستان در كلينيك تخصصى سرطان يستان جهاد

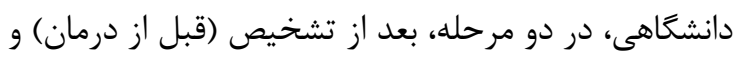

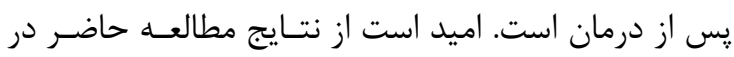
راستاى ارتقا سطح كيفيت زندكى بيمار، همسر و خـانواده بيمار بهره كرفته شود.

\section{مواد و روشها}

يزوهش حاضر يك مطالعه توصيفى است و جمعيت مـورد

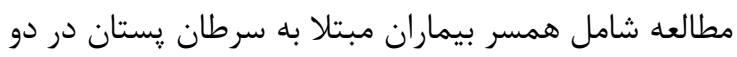

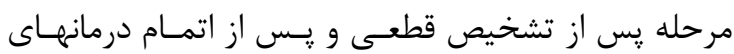

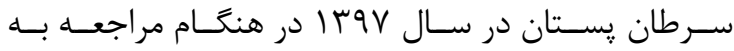

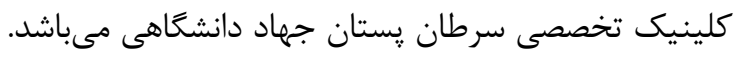
حجم نمونه بر اساس فرمول هاى آمارى محاسبه و با توجه

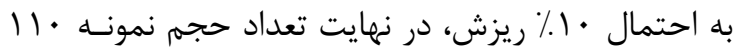

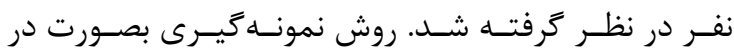

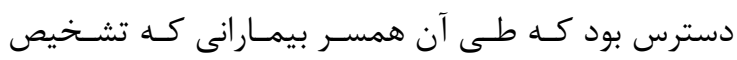

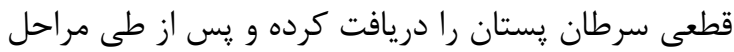

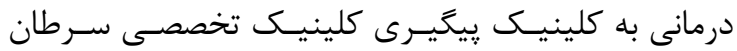

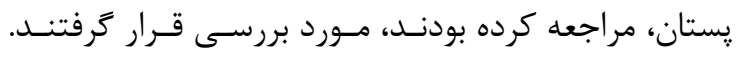
مصاحبه با هر يك از همسران با رضايت ايشان و همجنين بردين كسب رضايت خود بيمار انجام شـد. همجنــين توضـيحات

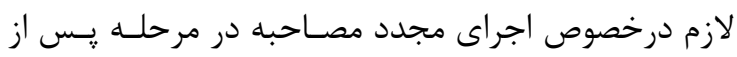

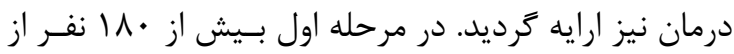
همسران مورد مصاحبه قرار گرفتند. در مرحله دوم امكـان

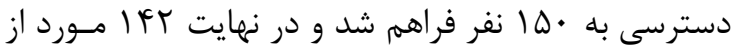

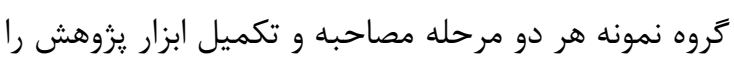

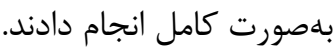


معيارهاى خروج از مطالعه: عدم رضايت براى شركت در

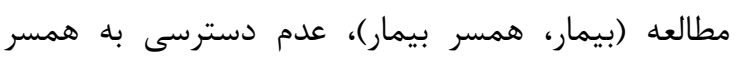
بيمار، ابتلا به بيمارى روانيزشكى يا مصرف داروهاى

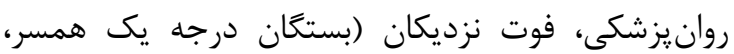

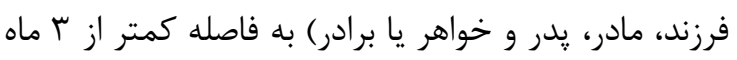

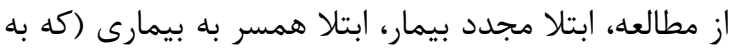

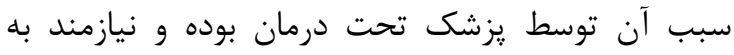
درمان طولانى باشد).

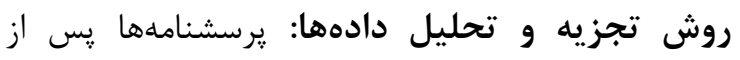

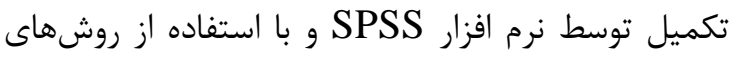

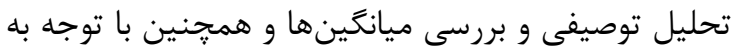

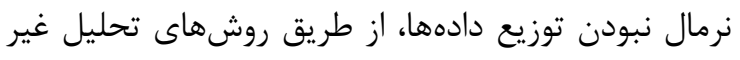
يارامتريك ويلكاكسون مورد تجزيه و تحليل قرار كرفتنند.

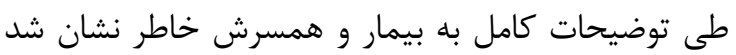

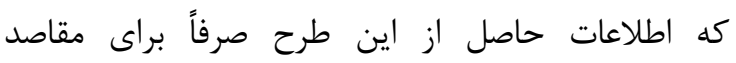

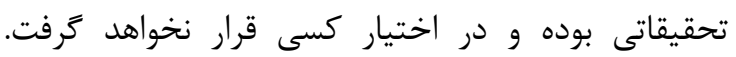

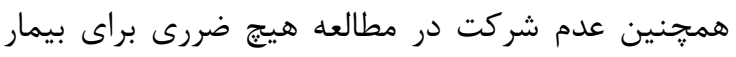
نداشته و در درمان و مراقبتهاى بعدى ايشان هيجَّونه خللى وارد نخواهد شد. به همسر بيمار اطمينان داده شد شد إندان

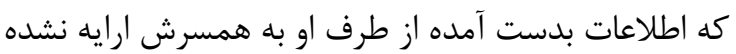
و محرمانه جهت امر تحقيق نزد محقق خواهد ماند.

\section{كافتهها}

درخصوص اطلاعات جمعيت شناختى، ميانكين سنى همسران اه سال بود. از نظر تحصيلات، اغلب همسران آنسان

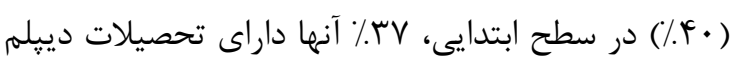

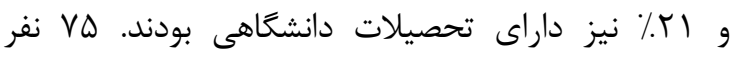

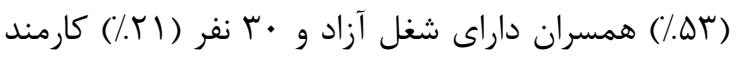

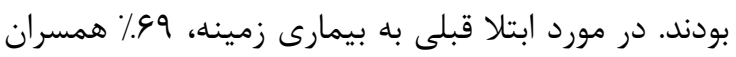

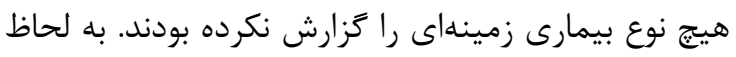

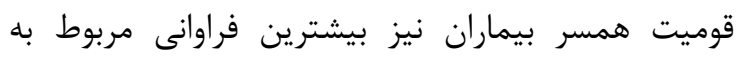

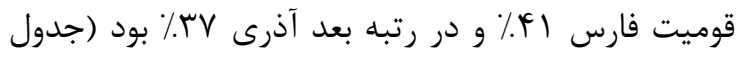

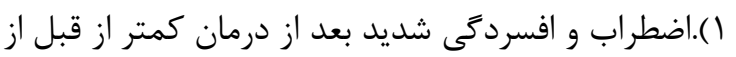

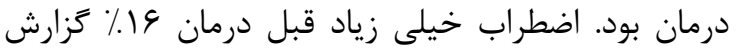

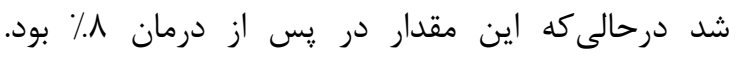

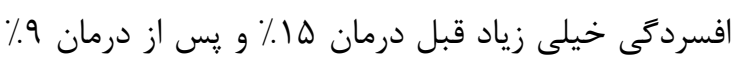

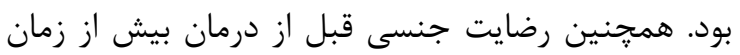

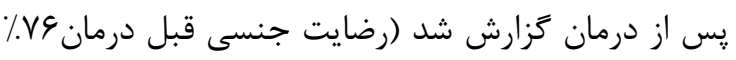

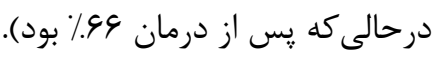

خستخى (Y سوال)، سلامت روحى (ه سوال)، عملكرد

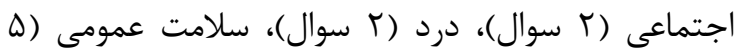

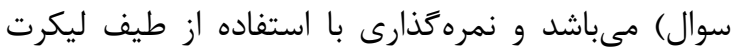

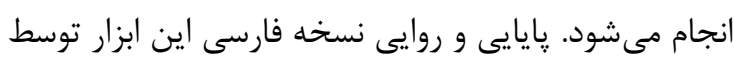

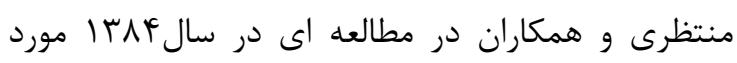

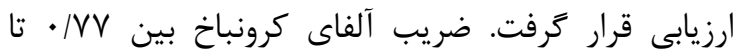

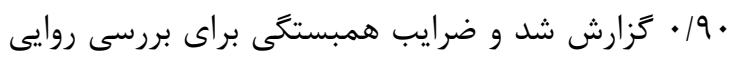

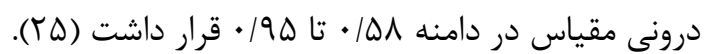

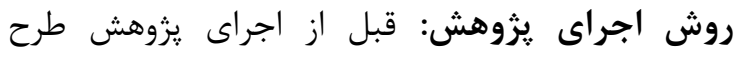

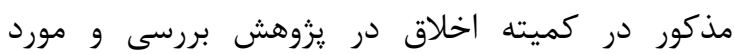

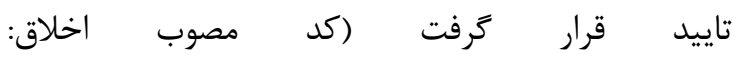
تابر ابزارهاى يزوهش در دو نوبت، يك بار يس از تشخيص

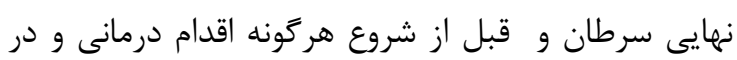

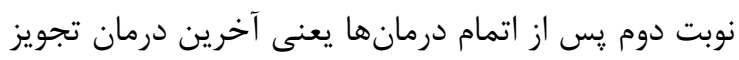
شده براى بيمار و در زمانى كه بيمار به كلينيك يُ بيخيرى اين مركز معرفى شدند (اولين مراجعه به كلينيك يِيخيرى)

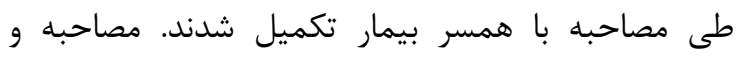

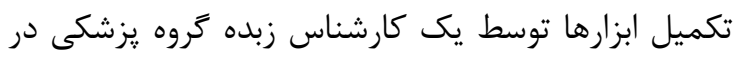

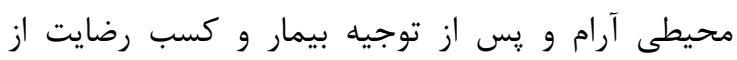

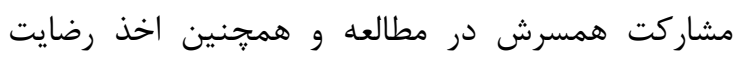

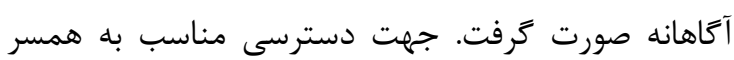
بيماران در ابتداى تشخيص، توضيحات لازم براى بيمار

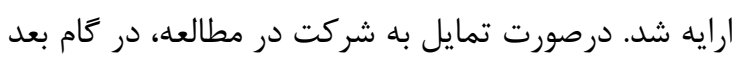

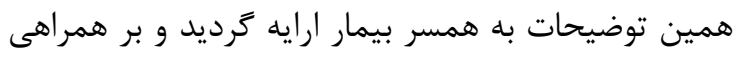

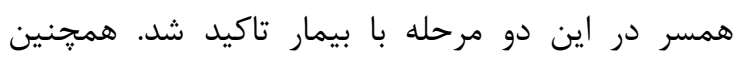

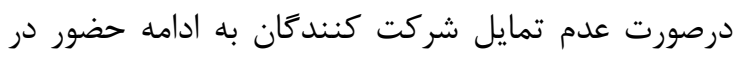

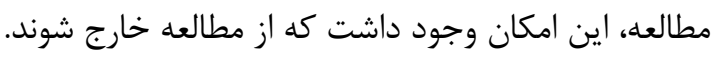
معيارهاى ورود به مطالعه: معرفى همسر توسط بيمار،

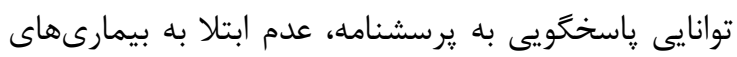

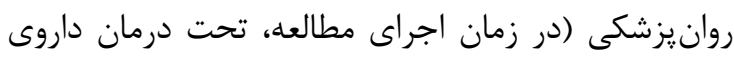

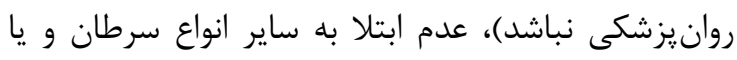

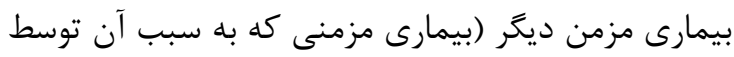
يزشك تحت درمان باشد)، دريافت تشخيص سرطان برئ مراى

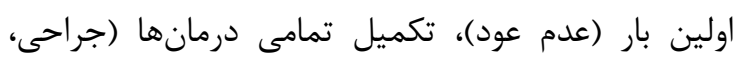

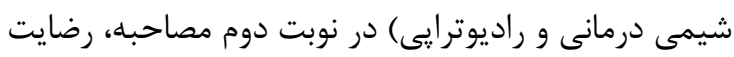
بيمار براى شركت همسرش در مطالعه، رضايت همسر بيمار از شركت در مطالعه. 


\begin{tabular}{|c|c|c|}
\hline د ن ارصد & 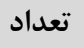 & \\
\hline & & 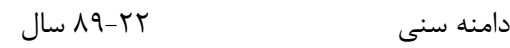 \\
\hline & & ميانخين (انحراف استاندارد) • (1) اه سال \\
\hline & & تحصيلات \\
\hline r. & $\Delta \Lambda$ & 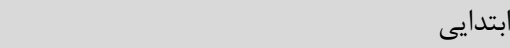 \\
\hline re & $\Delta r$ & دييلم \\
\hline \multirow[t]{2}{*}{ rI } & r & دانشعاهى/ دكترا \\
\hline & & 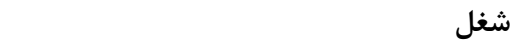 \\
\hline r & r & بيكار \\
\hline$\Delta r$ & Va & 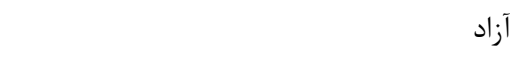 \\
\hline rI & r. & 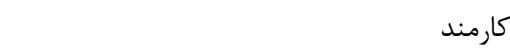 \\
\hline \multirow[t]{2}{*}{ Tr } & re & بازنشسته \\
\hline & & بيمارى زمينهاى همسر \\
\hline 99 & 91 & 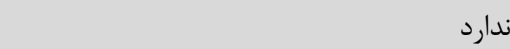 \\
\hline \multirow[t]{2}{*}{ r. } & fr & 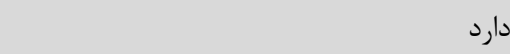 \\
\hline & & 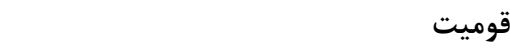 \\
\hline (4) & $\Delta \wedge$ & 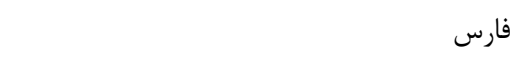 \\
\hline 11 & 10 & كيلك- مازندرانى \\
\hline 9 & ir & ل ل ل ابروجردى \\
\hline$r v$ & $\Delta r$ & آذ آذرى زبان \\
\hline \multirow[t]{2}{*}{ r } & f & 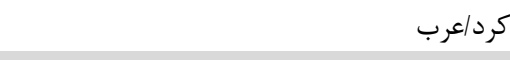 \\
\hline & & ضطراب همسر قبل از درمان بيمار \\
\hline$\Delta F$ & VA & 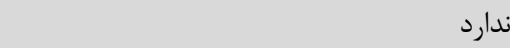 \\
\hline \multirow[t]{2}{*}{ is } & q & 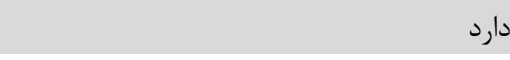 \\
\hline & & اضطراب يس از درمان بيمار \\
\hline vı & 111 & 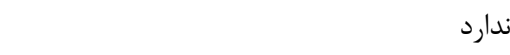 \\
\hline \multirow[t]{2}{*}{ tr } & rt & دارد \\
\hline & & افسردَى همسر قبل از درمان بيمار \\
\hline$\Delta \varphi$ & $\wedge$. & 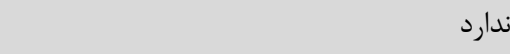 \\
\hline \multirow[t]{2}{*}{ fr } & st & 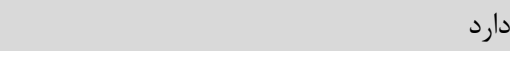 \\
\hline & & افسردكى همسر بعد از درمان بيمار \\
\hline 99 & 94 & 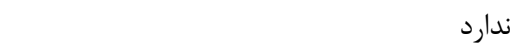 \\
\hline \multirow[t]{2}{*}{ ry } & is & 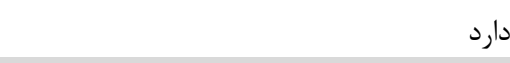 \\
\hline & & رضايت جنسى قبل از درمان \\
\hline ve & 1.9 & 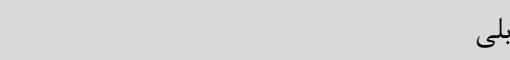 \\
\hline \multirow[t]{2}{*}{ tr } & ru & خير \\
\hline & & رضايت جنسى پِ از درمان \\
\hline 99 & 90 & 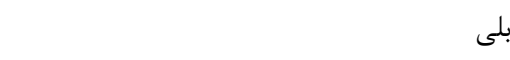 \\
\hline rF & FV & خير \\
\hline
\end{tabular}

آزمون ويلكاكسون بررسى شد. همان گونه كه در جـدول

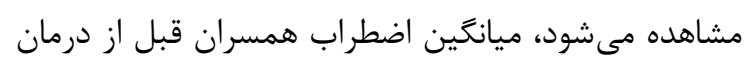

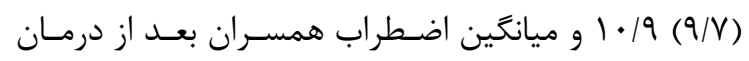

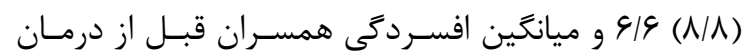

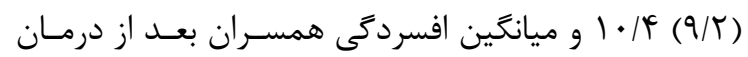

اضطراب و افسردكى همسر بيمــاران قبــل و بعـد از

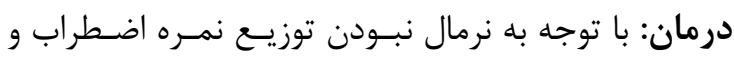

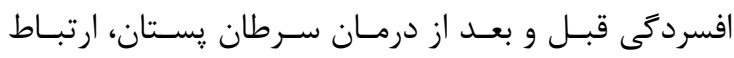
متغيرهاى فوق در دو مقطع اندازهيرى شده با اسـتفاده از بـاز 
بررسى قرار كرفت. نتايج اين آزمون در هـر يـك از خـــده

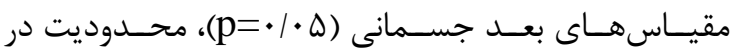

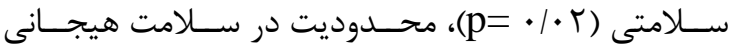

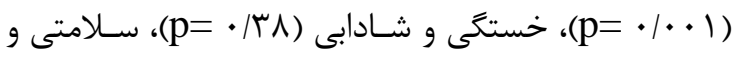

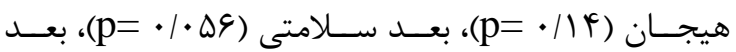

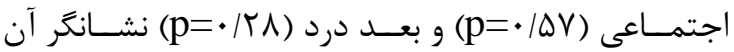
اسـت كــه مشــكلات جســمانى، محسـدوديت ســلامتى و محدوديت سلامتى هيجانى همسر در قبل و بعد از درمـان داراى اختلاف معنادارى مىباشد (جدول س).
N/9 (N/9)

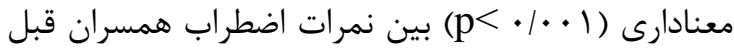
و بعـد از درمــان مشــاهده شـد. همجنـــين بــين نمــرات

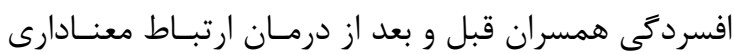

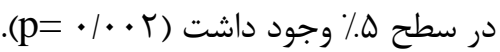

ابعاد كيفيت زندكَى همســر بيمــاران قبـل و بعـد از درمان: با توجه به نرمال نبودن توزيع نمره كيفيت زندگى همسر بيماران، تغييرات هشت خرده مقياس مربوطه، قبـل

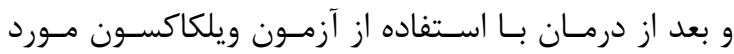

جدول ז: ميانگين و انحراف استاندارد نمرات اضطراب و افسردگى همسران در قبل و بعد از درمان بيمار

\begin{tabular}{|c|c|c|c|}
\hline $\mathbf{P}$ & ميانگين (انحراف استاندارد) بعد از درمان & ميانكين (انحراف استاندارد) قبل از درمان & \\
\hline$<\cdot|\cdot|$ & $\varepsilon / \varepsilon(\Lambda / \Lambda)$ & $1 \cdot 19(9 / \mathrm{V})$ & اضطراب \\
\hline$<\cdot / \cdot \cdot r$ & $\Lambda / 9(\Lambda / 9)$ & $1 \cdot / 4(9 / r)$ & افسردكى \\
\hline
\end{tabular}

جدول بّ: ميانكين و انحراف استاندارد ابعاد كيفيت زندكى همسران در قبل و بعد از درمان بيمار

\begin{tabular}{|c|c|c|c|}
\hline $\mathbf{P}$ & $\begin{array}{c}\text { ميانغين (انحراف استاندارد) } \\
\text { بعد از درمان }\end{array}$ & ميانگين (انحراف استاندارد) & \\
\hline$\cdot 1 \cdot \Delta$ & $9 r \cdot / 1(9 \Delta)$ & GTI/G (ᄉI) & بعد جسمانى \\
\hline$\cdot / \cdot T V$ & $r r F / l(r q)$ & $r \mu q / \mathcal{F}(f))$ & بعد محدوديت در سلامتى \\
\hline$\cdot 1 \cdot \cdot 1$ & $r \Delta T / \Delta(Y)$ & $r \Delta 9 / \Delta(T r)$ & بعد محدوديت در سلامت هيجانى \\
\hline$\cdot / \pi \wedge \Delta$ & $r \cdot F / F(F F)$ & $199 / \cdot r(Y \Delta / \Delta)$ & بعد خستگى و شادابى \\
\hline.$/ 1 F F$ & $r \Delta \Gamma / V(\Delta r)$ & $Y F \Delta / G(D F)$ & بعد سلامتى و هيجان \\
\hline$\cdot 1 \cdot \Delta \varphi$ & $r q V / T(F T)$ & $r q 1 / r(r \varepsilon)$ & بعد سلامتى \\
\hline$\cdot / \Delta V$ & $\| V / V(T r)$ & $119 / r(r r)$ & بعد اجتماعى \\
\hline$\cdot / r \wedge 9$ & $|F| / K(F \wedge)$ & $\mid r q / \cdot r(r q / \Delta)$ & 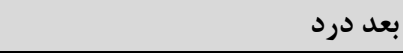 \\
\hline
\end{tabular}

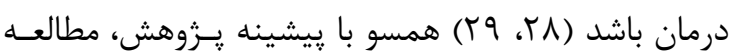
حاضر نيز نشان مى دهد كه وضـعيت سـلامت همسـران نشانهاى افسردگى تاثير معنادارى در كاهش بعد سـلامت ماه بعد از تشخيص بهتر از زمان تشخيص است و همسران محدوديت كمترى را در زمينه سلامت احساس مسى كننـد.

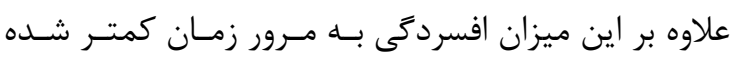

وكيفيت زندگى در ابعاد مختلف نيز بهبود يافته است. همسران بهدليل ساعتها مراقبت و در نتيجه خستخى زياد و تغيير در وضعيت كارى خود محدوديت بيشترى در رفــاه

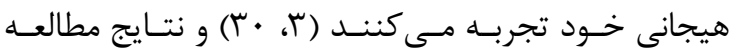
حاضر نيز نشانگر وجود محدوديتهايى در سلامت هيجانى

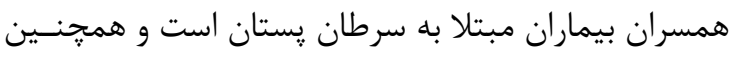

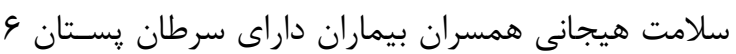
مـاه يـس از تشـخيص وضـعيت بهتـرى نسـبت بــه زمـان

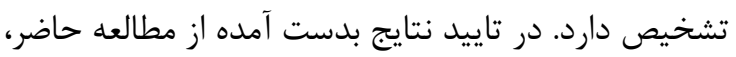
جسمانى كيفيت زندگى همسران بيماران مبتلا به سرطان

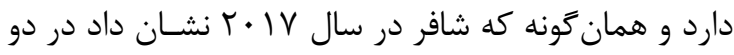

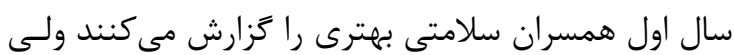

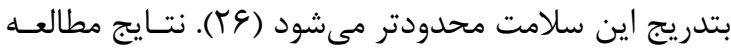

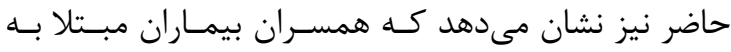
سرطان پستان محدوديتهايى در سلامت جسـمانى خـود تجربه مى كنند. اين تبيين وجود دارد كه مراقبت از بيمـار

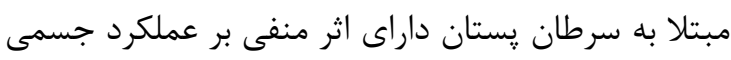
و روانى و اجتماعى همسران مىباشد (TV). بلهنر مىرسد كه ميزان اضطراب و افسردگى همسر بيمار مبتلا به سرطان يستان بلافاصله يس از تشخيص بيشتر از

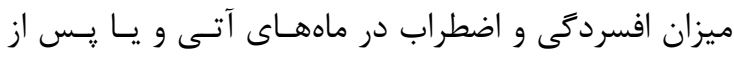




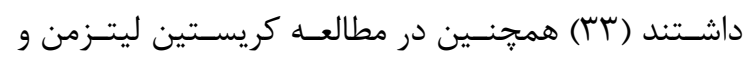

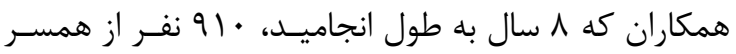

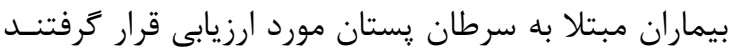

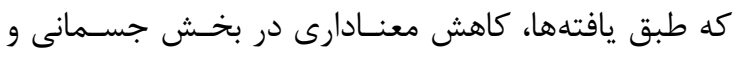

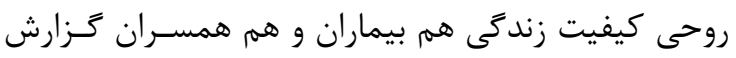

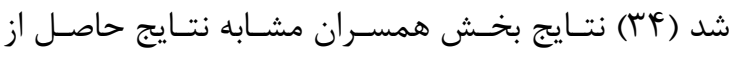
مطالعه حاضر است. نتايج مطالعه حاضر نشان مى دهد كه سطوح يايين كيفيت

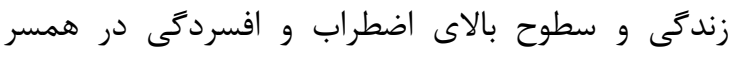

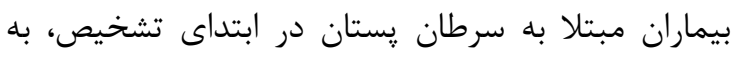

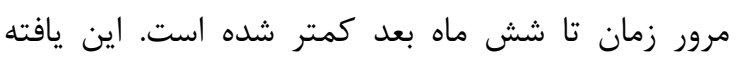

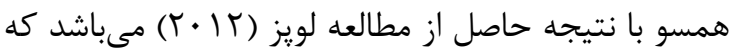

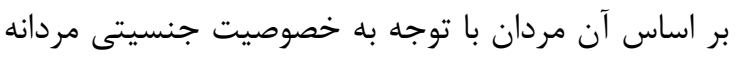
غالباً در اثر فشارهاى اجتماعى بروز هيجانى كمترى دان دارند.

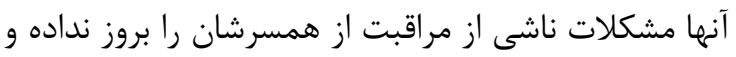

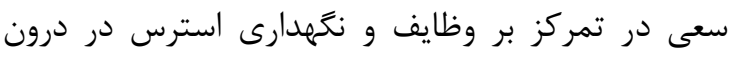

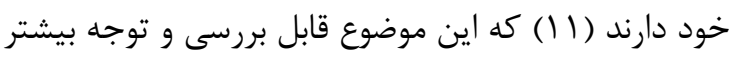

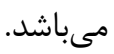
لازم به ذكر است كه نتايج يزوهش حاضر بايد با توجه به

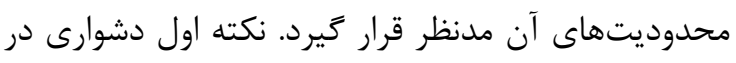

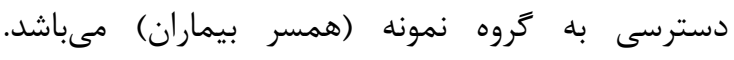

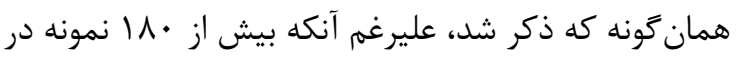

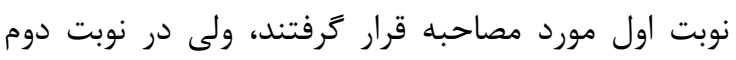

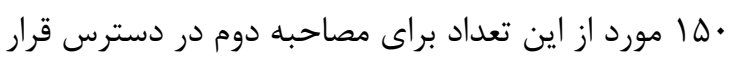
داشته و حاضر به همكارى بودند.

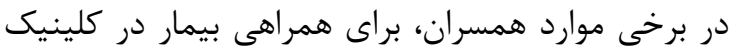

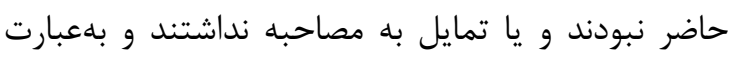

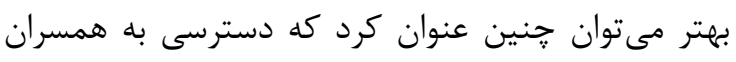

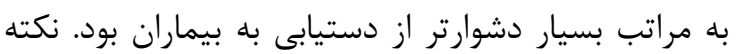

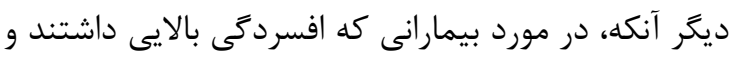

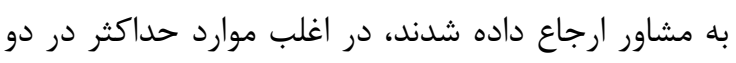
جلسه مشاوره حضور ييدا مى كردند و در تعداد جلسات

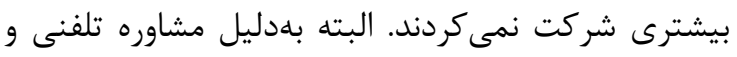

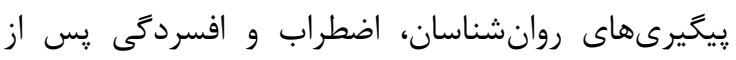
درمان به مراتب كاهش يافت.

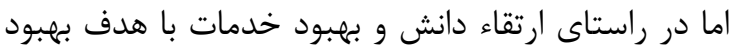

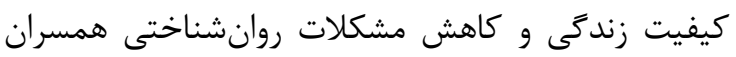

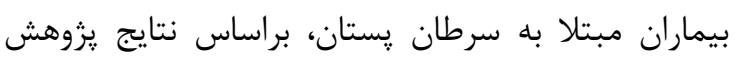

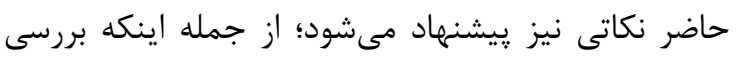

شور و ماتئوس در مطالعاتى يـك گَـروه از همســـان زنـان

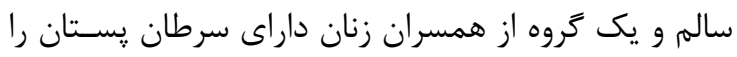

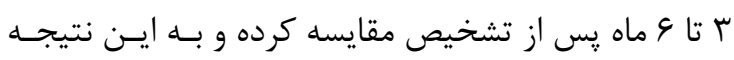
رسيدند كه سلامت جسـمى و روانسى و هيجـانى در كـروه

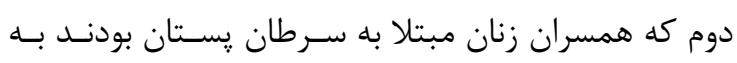

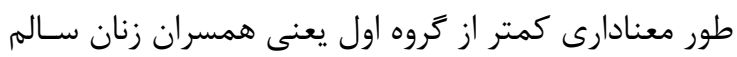

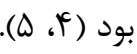

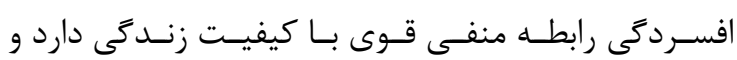

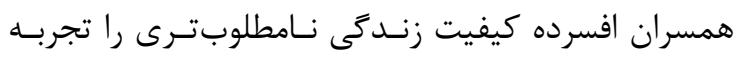

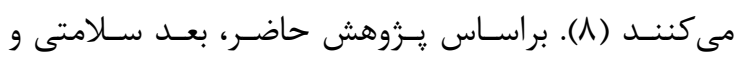

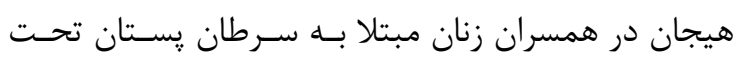
تاثير بيمارى همسرشان قرار دارد. نتايج مطالعات ديكر نيز

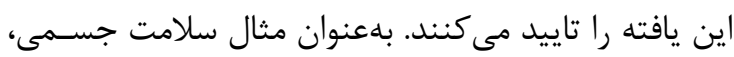

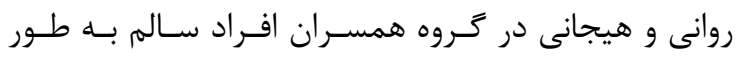

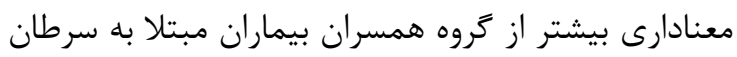
يستان كزارش شده است (ه، ^).

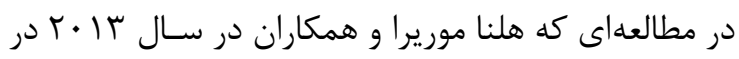

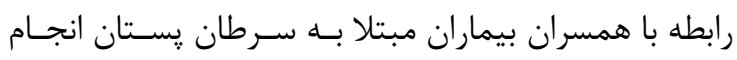

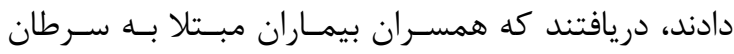

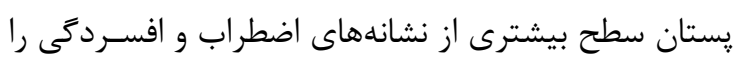

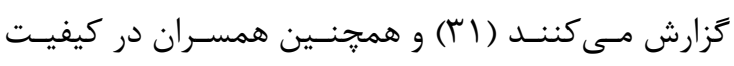

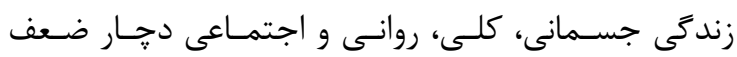

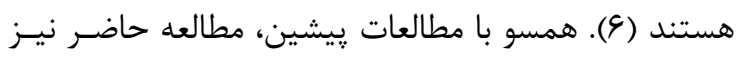

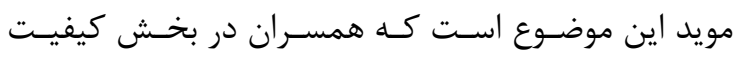

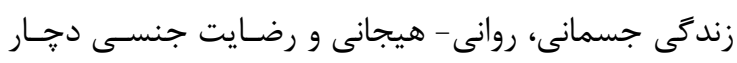

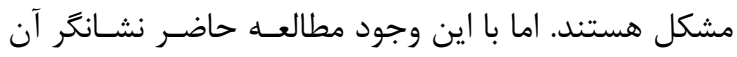

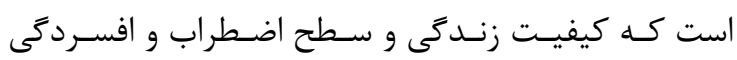

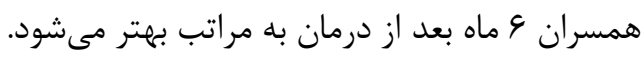

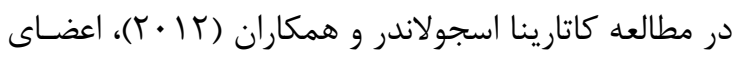

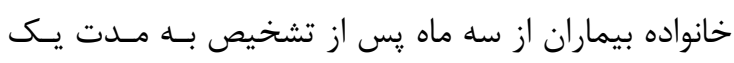

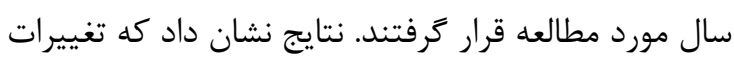

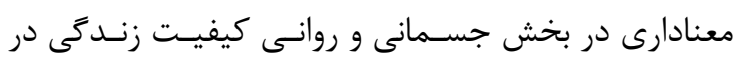

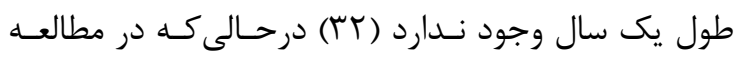

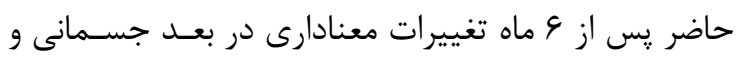
هيجانى مشاهده شد.

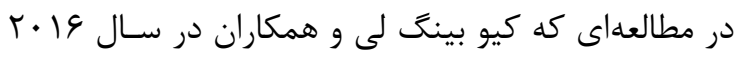

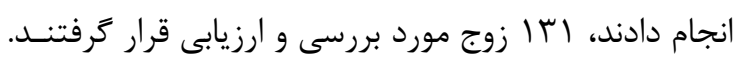

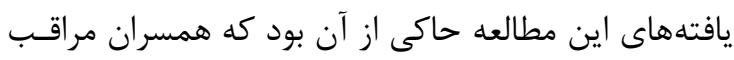
سطح بالاترى از اضطراب و افسردىى را نسبت به بيمـاران إن بهان 


$$
\begin{aligned}
& \text { مى كنند ولى سطوح مشكلات جسمانى در اين افراد در } \\
& \text { زمان يس از درمان بيشتر از زمان قبل از درمان مى باشدات }
\end{aligned}
$$

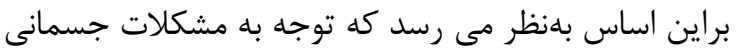

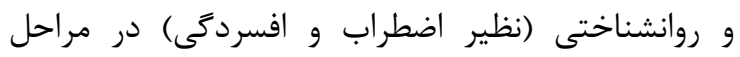

$$
\begin{aligned}
& \text { مختلف تشخيص و درمان توجه ويزهاى را مىطلبد و واتخاذ } \\
& \text { سياستهاى درمانى در حيطه خدمات روانشناختى براى دراي }
\end{aligned}
$$

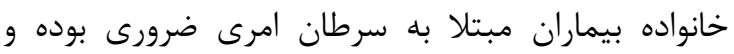

$$
\begin{aligned}
& \text { مستلزم پِيخيرى بيشترى مىباشد. }
\end{aligned}
$$

\section{تشكر و قدردانى}

بدين وسيله از تمامى بيماران و همسر انشان كه با صـبورى نهايت همكارى را با يزوهشكران اين مركز داشـتند نهايست

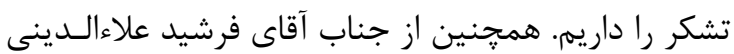

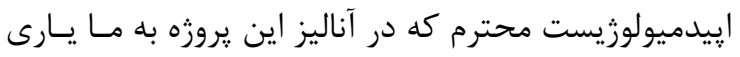

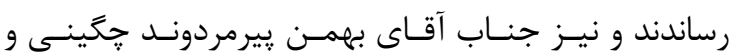

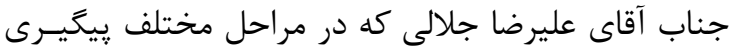
همسر بيماران ما رايارى كردند نهايت تشكر را داريم.

\section{تعارض منافع}

$$
\begin{aligned}
& \text { نويسندكان اعلام مى دارنـد كـهـ هـيـه تعـارض منـافعى در } \\
& \text { يزروهش حاضر وجود ندارد. }
\end{aligned}
$$

\section{References}

1. Sajadian, A., L. Hydary, and P. Mokhtari Hesari, Common Breast Cancer Family Care Giving Problems. Iranian Quarterly Journal of Breast Diseases, 2015; 8(2): 7-14.

2. Catania, A. M., Sammut Scerri, C., \& Catania, G. J., Men's experience of their female partners' breast cancer diagnosis, breast surgery and oncological treatment. Journal of Clinical Nursing. 2019; doi:10.1111/jocn.14800

3. Al-Azri, M., et al., Psychosocial impact of breast cancer diagnosis among Omani women. Oman medical journal, 2014; 29(6): 437.

4. Mantani, T., et al., Factors related to anxiety and depression in women with breast cancer and their husbands: role of alexithymia and family functioning. Supportive Care in Cancer, 2007; 15(7): 859-68.
نيازهاى ويزه همسران و همجنين بررسى سبكهاى مقابله آنان در رابطه با بيمار مبتلا به سرطان در مطالعات آتى هم مورد ارزيابى قرار گيرد. همجنين زيشنههاد مىشود كه

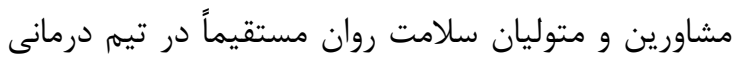
حضور داشته و به ارايه خدمات به بيمار، همسر و خانواده بيمار بيردازند. افزايش سطوح دانش و اطلاعات براى

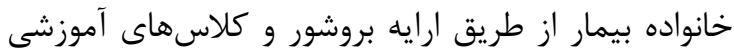

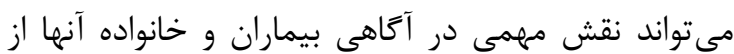
اثرات روانشناختى بيمارى بر بيمار و خانواده بيمار داشته باشد. لازم است در مورد مسايل روانشناختى و همجنين درخصوص روابط زناشويى يس از سرطان يستان اطلاعات

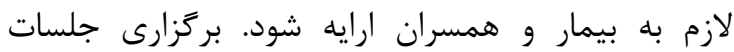
مشاوره براى خانواده بيماران و همسرانشان در راستاى ران ييشگيرى از آسيبهاى احتمالى و درمان مشكلات موجود نيز اقدامى مفيد خواهد بود. خصوصاً دريافت مشاوره إن ميندان روانشناختى همزمان با دريافت تشخيص سرطان يستان

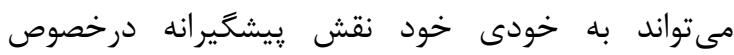

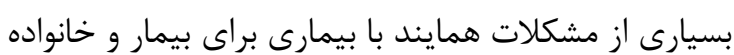
بيمار داشته باشد.

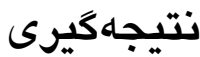

همسران بيماران مبتلا به سرطان يُتان در مرحله پٍ از درمان سطوح يايينترى از اضطراب و افسردگى را تجربه

5. Hasson-Ohayon, I., et al., Women with advanced breast cancer and their spouses: diversity of support and psychological distress. Psycho-oncology, 2010; 19(11): 1195-204.

6. Cormio, C., et al., Psychological well-being and posttraumatic growth in caregivers of cancer patients. Front psycho, 2014; 5: 1342.

7. Milbury, K. and H. Badr, Sexual problems, communication patterns, and depressive symptoms in couples coping with metastatic breast cancer. Psycho-Oncology,2013;4(22): 814-822.

8. Wagner, C.D., S.M. Bigatti, and A.M. Storniolo, Quality of life of husbands of women with breast cancer. Psycho-Oncology, 2006; 15(2): 109-20.

9. Fletcher, K.A., F.M. Lewis, and M.R. Haberman, Cancer-related concerns of spouses 
of women with breast cancer. Psycho-Oncology, 2010; 19(10): 1094-101.

10. Kim, Y., et al., Needs assessment of family caregivers of cancer survivors: three cohorts comparison. Psycho-Oncology, 2010; 19(6): 573-82.

11. Lopez, V., G. Copp, and A. Molassiotis, Male caregivers of patients with breast and gynecologic cancer: experiences from caring for their spouses and partners. Cancer Nurs, 2012; 35(6): 402-10.

12. Dorros, S.M., C. Segrin, and T.A. Badger, Cancer survivors' and partners' key concerns and quality of life. Psychology \& health, 2017; 32(11): 1407-27.

13. Lambert, S., et al., Trajectories of mental and physical functioning among spouse caregivers of cancer survivors over the first five years following the diagnosis. Patient education and counseling, 2017; 100(6): 1213-21.

14. Drabe, N., et al., Mutual associations between patients' and partners' depression and quality of life with respect to relationship quality, physical complaints, and sense of coherence in couples coping with cancer. Psycho-Oncology, 2015; 24(4): 442-50.

15. Shin, J., et al., Underestimated caregiver burden by cancer patients and its association with quality of life, depression and anxiety among caregivers. Eur J Cancer, 2018; 27(2): e12814.

16. Chan, J.S., et al., Dyadic associations between psychological distress and sleep disturbance among Chinese patients with cancer and their spouses. Psycho-oncology, 2017; 26(6): 856-61.

17. Taleghani, F., Men's Sexual Issues After Breast Cancer in Their Wives. Cancer Nurs, 2012; 35(3): e237.

18. Gorji, M.A.H., et al., Quality of life and depression in caregivers of patients with breast cancer. BMC research notes, 2012; 5(1): 310.

19. Khanjari, S., F. Oskouie, and A. LangiusEklöf, Lower sense of coherence, negative religious coping, and disease severity as indicators of a decrease in quality of life in Iranian family caregivers of relatives with breast cancer during the first 6 months after diagnosis. Cancer nurs, 2012; 35(2): 148-56.

20. Soleimani, M.A., et al., Death anxiety and quality of life in Iranian caregivers of patients with cancer. Cancer nurs, 2017; 40(1): e1-10.

21. Beck, A.T., R.A. Steer, and M.G. Carbin, Psychometric properties of the Beck Depression
Inventory: Twenty-five years of evaluation. Clin Psychol Rev, 1988; 8(1): 77-100.

22. Dabson, K. and K.P. Mohammad, Psychometric characteristics of Beck depression inventory-II in patients with major depressive disorder. rehabilitation, 2007.

23. Beck, A.T., et al., An inventory for measuring clinical anxiety: psychometric properties. Journal of consulting and clinical psychology, 1988; 56(6): 893

24. Kaviani, H. and A. Mousavi, Psychometric properties of the Persian version of Beck Anxiety Inventory (BAI). Tehran University Medical Journal TUMS Publications, 2008; 66(2): 136-40.

25. Montazeri, A., et al., The Short Form Health Survey (SF-36): translation and validation study of the Iranian version. Qual Life Res, 2005; 14(3): $875-82$.

26. Chronopoulou, K, Sakkas, D, Damigos, D, Caregiving burden and psychological distress of breast cancer patients' husbands after mastectomy. International Journal of Caring Sciences, 2016; 9(30): 909-13.

27. Alacacioglu, A., et al., Quality of life, anxiety and depression in Turkish breast cancer patients and in their husbands. Med Mycol, 2009; 26(4): 415.

28. Badger, T., et al., Depression and anxiety in women with breast cancer and their partners. Nurs Res, 2007; 56(1): 44-53.

29. Grunfeld, E., et al., Family caregiver burden: results of a longitudinal study of breast cancer patients and their principal caregivers. Cmaj, 2004; 170(12): 1795-801.

30. Wadhwa, D., et al., Quality of life and mental health in caregivers of outpatients with advanced cancer. Psycho-Oncology, 2013; 22(2): 403-10.

31. Moreira, H. and M.C. Canavarro, Psychosocial adjustment and marital intimacy among partners of patients with breast cancer: a comparison study with partners of healthy women. J Psychosoc Oncol, 2013; 31(3): 282304.

32. Sjolander, C., et al., Health-related quality of life in family members of patients with an advanced cancer diagnosis: A one-year prospective study. Health and quality of life outcomes, 2012; 10(1): 89.

33. Li, Q., et al., Factors influencing the healthrelated quality of life of Chinese advanced cancer patients and their spousal caregivers: a 
cross-sectional study. BMC palliat care, 2016; 15(1): 72 .

34. Litzelman, K., et al., Adequacy of Depression Treatment in Spouses of Cancer Survivors: Findings From a Nationally
Representative US Survey. J Gen Intern Med, 2018; 33(6): 869-76. 